\title{
15. PRELIMINARY ELECTRICAL MEASUREMENTS OF CORE SAMPLES, DSDP LEG 37
}

\author{
T.J. Kaisube, J. Frechette, and L.S. Collett, Geological Survey of Canada, Ottawa, Canada
}

\section{INTRODUCTION}

Preliminary measurements have been completed on the electrical properties of core samples from the Deep Sea Drilling Project (6 samples from Hudson Deep Drill '74 site survey, and 10 samples from Glomar Challenger Leg 37). The frequency range of measurement is from 1.0 to $10^{6} \mathrm{~Hz}$, and the measured parameters are parallel resistivity $\left(\rho_{\mathrm{p}}\right)$ or resistivity and dissipation factor $(D)$. Because the thickness of the core samples measured ranges from $2.0-3.0 \mathrm{~cm}$, measurement problems occurred at the higher frequencies (mainly above $10^{4} \mathrm{~Hz}$ ). And because to date only the two electrode system has been applied, not all measurements are free from electrode effects at the lower frequencies. It is also not certain whether the samples have been measured under adequate conditions, since some of them have been saturated with seawater (Glomar Challenger samples), and others with ground water (Hudson samples). However, the measurements at the frequencies ranging from 10 to $10^{4}$ $\mathrm{Hz}$ are generally free from erroneous effects and indicate the general trend of the electrical properties of these core samples.

\section{SAMPLES AND PREPARATION}

Samples measured in this study are cores taken from the grab samples from Hudson Deep Drill ' 74 site (6 samples) and from Glomar Challenger Leg 37 (10 samples). The samples were cut into cylinders with two parallel surfaces. Sample dimensions geometrical factor $(k)$ and other information is given in Tables 1 and 2. Glomar Challenger samples were received and measured in seawater saturated condition, and the Hudson samples were received in room-dry condition but measured under ground water (Ottawa River water) saturated condition.

The geometrical factor $(k)$ is determined from the equation:

$$
k=\frac{\text { area }}{\text { sample length }}
$$

Each sample diameter is $2.54 \times 10^{-2} \mathrm{~m}$ and area is $5.067 \times 10^{-4} \mathrm{~m}^{2}$.

\section{MEASURING SYSTEM AND PARAMETERS}

An automatic high impedance measuring system, controlled by a mini-computer, is used to measure the core samples. The measurement principles and electronic setup of the system are described in the paper by Gauvreau and Katsube (1975). This system makes direct measurement of the complex resistivity $\left(\rho^{*}\right)$ and dissipation factor $(D)$, and the parallel resistivity $\left(\rho_{\bar{p}}\right)$ is calculated from these measurements:

$$
\rho_{p}=\frac{D}{\rho^{*} \sqrt{ } 1+D^{2}}
$$

The interrelationship between the various parameters and their significance are described by Katsube (1975a, b). Parallel resistivity $\left(\rho_{\mathrm{p}}\right)$ is a parameter usually referred to as "Resistivity."

\section{RESULTS}

Typical results are shown in Figures 1 and 2 for a high impedance sample and a low impedance sample. These results are similar to the usual trends seen in the past work which is briefly summarized by Katsube (1975a), except for the increase of $D$ above $10^{5} \mathrm{~Hz}$. For the low impedance sample (Figure 2) there is a rapid rise of $\rho_{\mathrm{p}}$ and rapid decrease of $D$ with decreasing frequency below $10^{2} \mathrm{~Hz}$. The rise of $D$ at the maximum frequencies is due to stray capacitive effects of the system caused by the large length. Cole-Cole diagrams in the complex resistivity plane for the same two samples are shown in Figures 3 and 4. Methods of analysis of the Cole-Cole diagrams are discussed in Cole and Cole (1941) and Katsube (1975c). The analysis of Figure 4 suggests that the rapid decrease in $D$ at low frequencies (Figure 2) is due to electrode effects. The trend of the electrode effects being visible in Figure 2 (low impedance sample) but not in Figure 1 (high impedance sample) coincides with the results shown in the paper by Katsube (1975d). Results for $\rho_{\mathrm{p}}$ and $D$ which are thought to be free from erroneous effects (electrode and stray effects) are tabulated in Tables 3 and 4.

\section{DISCUSSION}

Resistivity or parallel resistivity $\left(\rho_{\mathrm{p}}\right)$ usually show little variation with frequency below the critical frequency (Katsube, 1975a; Katsube and Collett, 1973, 1974). This "little variation with frequency" is seen in all the results shown in Tables 3 and 4 . The large variation of resistivity with frequency is not seen in these results because the applied frequencies are not high enough.

Under the conditions where the resistivity shows a "little variation with frequency," Cole-Cole diagrams can be used to determine a single resistivity $\left(\rho_{\mathrm{p}}\right)$ value which represents a characteristic of the rock, and which does not contain any electrode or membrane polarization effects. According to Katsube (1975c), three zones: 
TABLE 1

Information on Samples from Glomar Challenger Leg 37

\begin{tabular}{|c|c|c|c|c|c|}
\hline Core & Section & $\begin{array}{l}\text { Depth } \\
\text { (m) }\end{array}$ & $\begin{array}{l}\text { Sample } \\
\text { Length } \\
(\mathrm{cm})\end{array}$ & $\begin{array}{l}\text { Geometric } \\
\text { Factor } \\
\text { (k) }\end{array}$ & Rock Type \\
\hline \multicolumn{6}{|c|}{ Hole 332A } \\
\hline $\begin{array}{r}7 \\
11 \\
17 \\
23 \\
30\end{array}$ & $\begin{array}{l}2 \\
1 \\
1 \\
1 \\
2\end{array}$ & $\begin{array}{l}113 \\
151 \\
208 \\
264 \\
332\end{array}$ & $\begin{array}{l}3.375 \\
2.885 \\
3.22 \\
2.83 \\
3.00\end{array}$ & $\begin{array}{l}0.015 \\
0.0176 \\
0.0157 \\
0.018 \\
0.0169\end{array}$ & $\begin{array}{l}\text { Sparsely phyric basalt } \\
\text { Sparsely phyric basalt } \\
\text { Aphyric basalt } \\
\text { Aphyric basalt } \\
\text { Plagioclase phyric basalt }\end{array}$ \\
\hline \multicolumn{6}{|c|}{ Hole 332B } \\
\hline $\begin{array}{r}6 \\
31\end{array}$ & $\begin{array}{l}1 \\
1\end{array}$ & $\begin{array}{l}284 \\
556\end{array}$ & $\begin{array}{l}3.46 \\
3.265\end{array}$ & $\begin{array}{l}0.0146 \\
0.0155\end{array}$ & $\begin{array}{l}\text { Aphyric basalt } \\
\text { Sparsely plagioclase phyric basalt }\end{array}$ \\
\hline \multicolumn{6}{|c|}{ Site 334} \\
\hline $\begin{array}{l}22 \\
24\end{array}$ & $\begin{array}{l}2 \\
4\end{array}$ & $\begin{array}{l}321 \\
343\end{array}$ & $\begin{array}{l}3.13 \\
2.42\end{array}$ & $\begin{array}{l}0.0162 \\
0.0209\end{array}$ & $\begin{array}{l}\text { Serpentinized plagioclase peridotite } \\
\text { Olivine-rich gabbro }\end{array}$ \\
\hline \multicolumn{6}{|c|}{ Site 335} \\
\hline 6 & 1 & 458 & 3.535 & 0.0143 & Sparse to moderate phyric basalt \\
\hline
\end{tabular}

TABLE 2

Information on Grab Samples

from Hudson Deep Drill '74 Site

\begin{tabular}{|c|c|c|c|}
\hline Sample & $\begin{array}{c}\text { Sample } \\
\text { Length } \\
(\mathrm{cm})\end{array}$ & $\begin{array}{c}\text { Factor } \\
\text { (k) }\end{array}$ & Rock Type \\
\hline $74-003,2-1 c$ & 2.13 & 0.0305 & Tholeiite (basalt) \\
\hline 74-003. 6-1c & 2.11 & 0.0221 & Tholeiite (basalt) \\
\hline $74-003,10-1 b$ & 2.098 & 0.0223 & Tholeiite (basalt) \\
\hline $74-003,10-2 a$ & 2.248 & 0.0202 & Tholeiite (basalt) \\
\hline $74-003,10-3 a$ & 2.088 & 0.0224 & Tholeiite (basalt) \\
\hline $74-003,10-4 b$ & 2.083 & 0.0229 & Tholeiite (basalt) \\
\hline
\end{tabular}

critical frequency zone, membrane polarization, and electrode polarization zone, can be seen as a result of analyzing the Cole-Cole diagrams. From Katsube (1975c) or Katsube and Collett (1974), it is evident that the left-hand side arc in Figure 3 (high impedance sample) is the critical frequency zone, and the small right-hand side arc is, perhaps, the membrane polarization zone with the electrode polarization zone further to the right not appearing. Thus the right-hand side interception of the arc and horizontal axis determines $\rho_{\mathrm{p}}$. The left hand side arc in Figure 4 (low impedance sample) is perhaps the membrane polarization zone with part of the electrode polarization zone seen on the right-hand side of it. The critical frequency zone cannot be seen in the figure, but can be expected to be seen on the left-hand side of the arc, if the measurements at higher frequencies were shown. Thus, the left-hand side interception of the arc and horizontal axis determines $\rho_{\mathrm{p}}$. $\rho_{\mathrm{p}}$ and the approximate frequency at which it is determined for all the samples are shown in Tables 3 and 4.

If four electrode systems were used at the lower frequencies, and the minimum frequency was extended to $10^{-2} \mathrm{~Hz}$, it is expected that the effect of membrane polarization (expressed by $\rho_{p^{2}}-\rho_{p^{1}}$ in Figure 4) and elec- trode polarization effects of metallic minerals in the rock sample (if they do exist) could be measured. And if the maximum frequency range was extended to $10^{8} \mathrm{~Hz}$, it is expected that further details of the critical frequency zone can be determined: values of the dielectric constant. This laboratory is set up to do these measurements, and these measurements will be the next step to be taken in this study.

The resistivity of rocks is dependent upon not only rock type, but also the type of liquid, type and amount of alteration in the pores, porosity, and other textural features. That is, two rocks which are identical in mineral and chemical composition can differ in resistivity due to differences in texture or type of pore liquid. At present, work is being carried out to standardize the type of liquid for saturating the rocks so that interlaboratory and regional comparisons can be made. However, in general, it is reasonable to expect resistivity values of basalt to be on the order of 500 to $10^{4} \mathrm{ohm}$ meters. The basalts from Glomar Challenger Leg 37 range from about 9 to $60 \mathrm{ohm}$-meters, and those from Hudson Deep Drill ' 74 range from about 70 to 540 ohm-meters. These values are smaller than the usual values, perhaps, due to the pores being saturated with seawater, or due to salt-water deposits in the pores dissolving into the pore water. Resistivity values of gabbro can be expected to be on the same order or larger than those of basalts. Thus, the $55 \mathrm{ohm}$-meter value for the gabbro Sample 334-24-4 is very low, perhaps for the same reason that the basalt samples show low resistivities. Serpentinized periodites show resistivities ranging from 5 to $10^{5}$ ohm-meters, and thus the 95 ohm-meter value for Sample 334-22-2 is normal.

Four sources of measurement error can be considered. The first source is instrumental error of the electronic measuring equipment which is in the order of $\pm 3.0 \%$. The second source is the sample-holder 


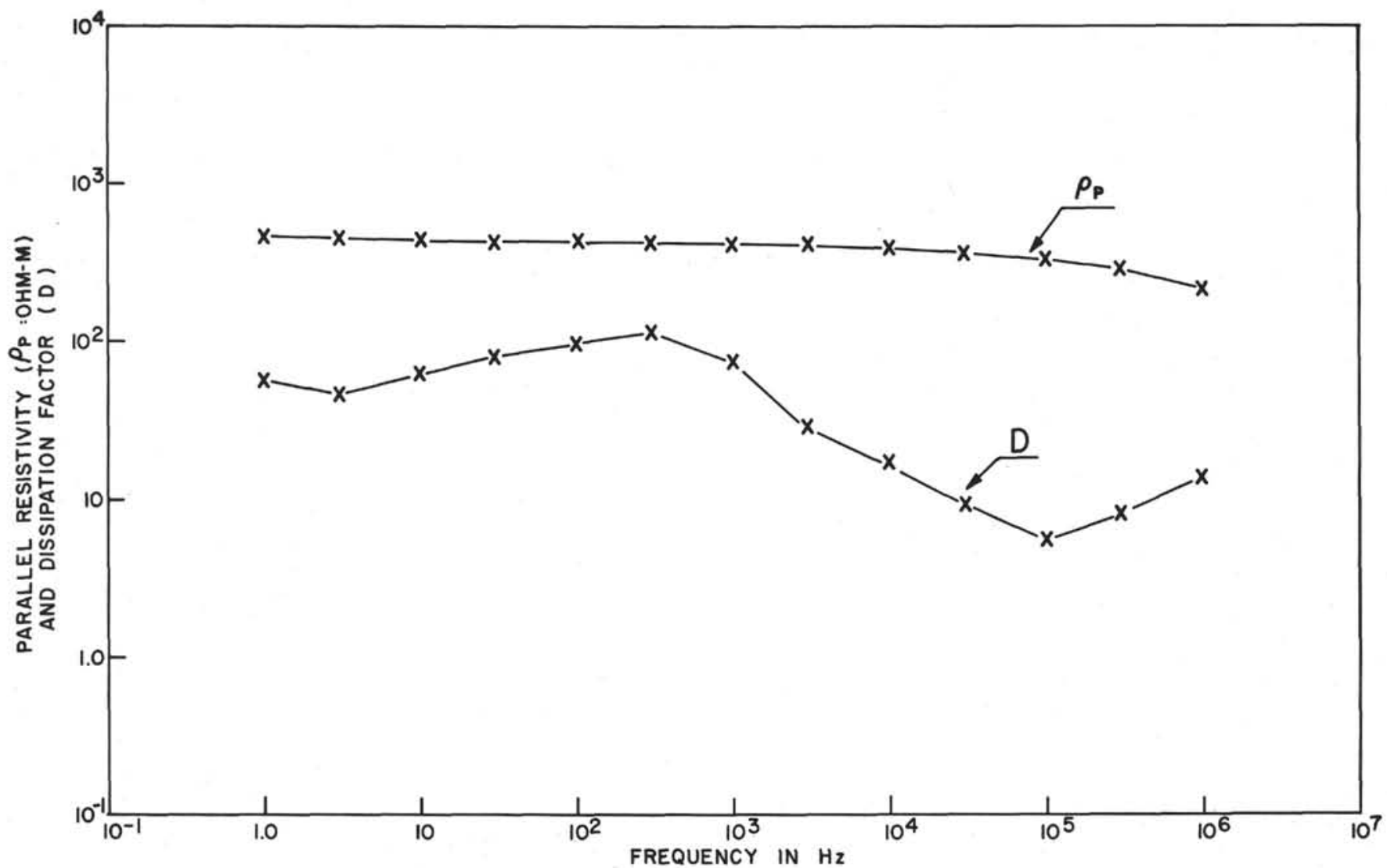

Figure 1. Parallel resistivity $\left(\rho_{\mathrm{p}}\right)$ or resistivity and dissipation factor (D) vs. frequency for a high impedance sample (74003, 2-1c).

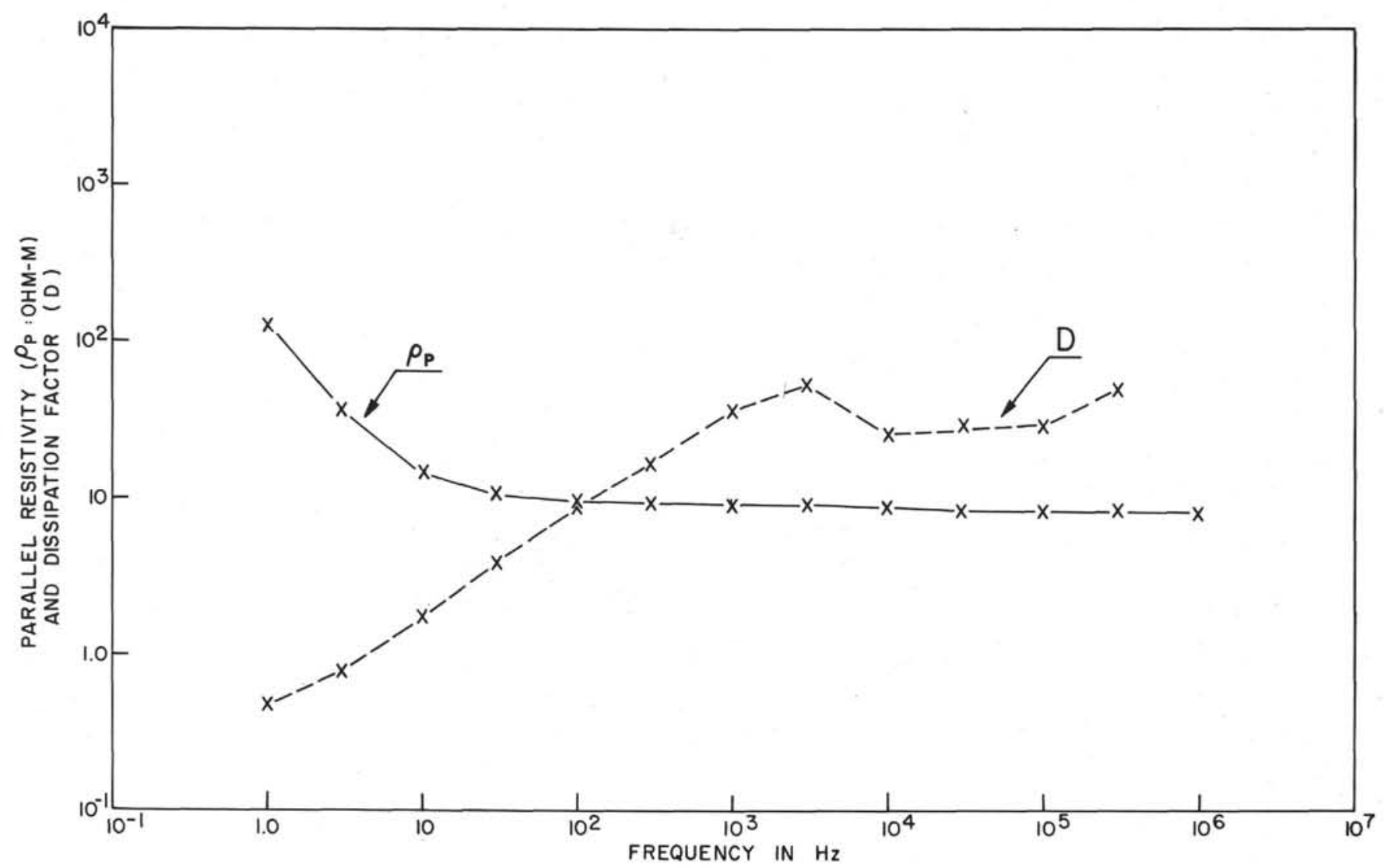

Figure 2. Parallel resistivity $\left(\rho_{\mathrm{p}}\right)$ or resistivity and dissipation factor (D) vs. frequency for a low impedance sample (332A-40-2). 


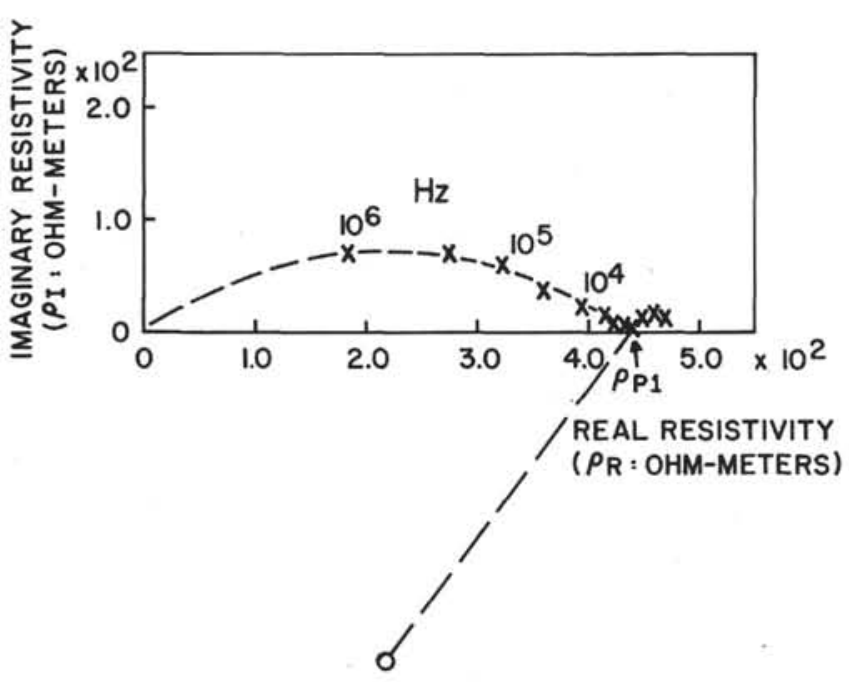

Figure 3. Cole-Cole diagram of the complex resistivity plane $\left(\rho_{\mathrm{R}}\right.$ : real resistivity, $\rho_{1}$ : imaginary resistivity) for Sample 74003, 2-1c.

system's error which is mainly caused by the electrochemical double-layer forming on the electrodes that contact the sample. This error is significant at the lower frequencies when the resistivity is low, but theoretically it is not contained in the value of $\rho_{p 1}$ in Tables 3 and 4 . The third source is sample handling error, which is mainly caused by evaporation of water from the surface of the specimen when moving it from container to sample holder or during measurement. Efforts are made to keep this error to a minimum, but empirically it is in the order of $\pm 3 \%$ to $6 \%$. The fourth source is due to the type of liquid used to saturate the rock specimens. The difference in pore liquids can cause the resistivity to vary by a factor of 10 to 100 . This is the reason that standardization of the type of liquids to saturate the rock is essential for making comparisons.

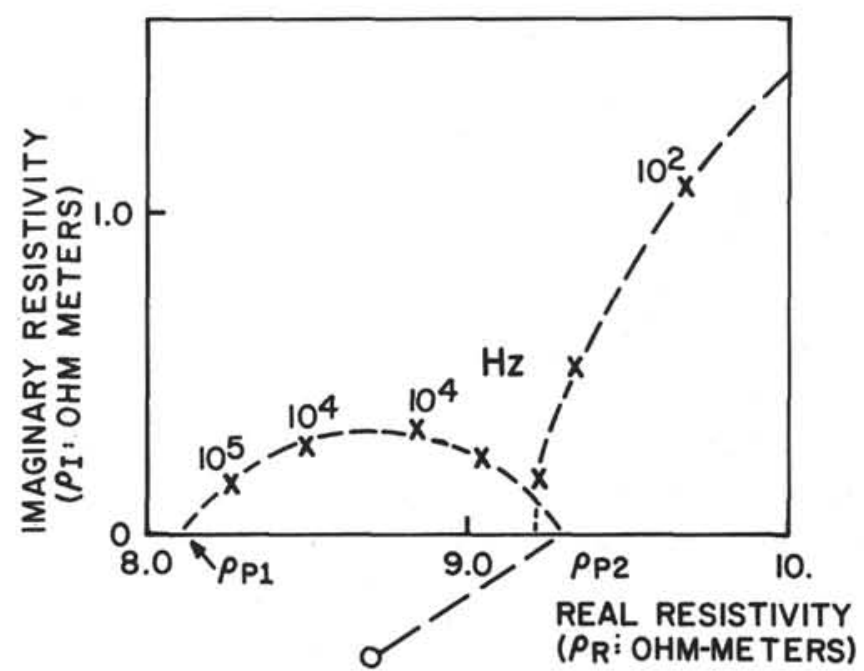

Figure 4. Cole-Cole diagram of the complex resistivity plane for Sample 332A-40-2.

\section{CONCLUSION}

Preliminary measurements of the electrical properties for 16 deep-sea samples have been carried out over the frequency range from 1.0 to $10^{6} \mathrm{~Hz}$. One of the parameters $\left(\rho_{\mathrm{p}}\right)$ which represents the resistivity of the samples is seen to range from 9.3 to $95 \mathrm{ohm}$-meters for the samples from Glomar Challenger Leg 37 drill holes, and from 120 to $540 \mathrm{ohm}$-meters for the grab samples from Hudson Deep Drill ' 74 site. The dissipation factor $(D)$ ranges from 1.0 to about 700 for these samples.

Four electrode measurements at the lower frequencies, measurement at frequencies above $10^{6} \mathrm{~Hz}$ and below $1.0 \mathrm{~Hz}$ measurements with different salinities are planned for the future using samples with smaller thicknesses. Petrographical correlation studies are also planned for the future.

TABLE 3

Parallel Resistivity $\left(\rho_{p}\right)$ or Resistivity and Dissipation Factor $(D)$ for Samples from Glomar Challenger Leg 37

\begin{tabular}{|c|c|c|c|c|c|c|}
\hline \multirow[b]{2}{*}{ Sample } & \multirow[b]{2}{*}{ Parameter } & \multicolumn{5}{|c|}{ Frequency } \\
\hline & & $10^{1}$ & $10^{2}$ & $10^{3}$ & $10^{4} \mathrm{~Hz}$ & $\begin{array}{c}\rho_{p 1} \\
\text { (Freq. }\end{array}$ \\
\hline $332 \mathrm{~A}-7-2$ & $\rho_{p}$ & $6.21 \mathrm{E} 1$ & $5.90 \mathrm{E} 1$ & $5.83 \mathrm{E} 1$ & $5.56 \mathrm{E} 1$ & 57 \\
\hline$(42)$ & $D$ & 9.8 & 50.9 & 644 & 52 & $\left(10^{4}\right)$ \\
\hline $332 \mathrm{~A}-12-1$ & $\rho_{p}$ & $3.31 \mathrm{E} 1$ & $2.95 \mathrm{E} 1$ & $2.81 \mathrm{E} 1$ & $2.61 \mathrm{E} 1$ & 28.8 \\
\hline (123) & $D$ & 5.2 & 20 & 38.7 & 21.9 & $\left(10^{3}\right)$ \\
\hline $332 \mathrm{~A}-27-1$ & $\rho_{p}$ & 2.491 & $2.28 \mathrm{E} 1$ & $2.14 \mathrm{E} 1$ & $1.99 \mathrm{E} 1$ & 22 \\
\hline (129) & $D$ & 13.8 & 23.3 & 35.7 & 23.5 & $\left(10^{2}\right)$ \\
\hline $332 \mathrm{~A}-34-1$ & $\rho_{p}$ & $4.55 \mathrm{E} 1$ & $4.22 \mathrm{E} 1$ & $4.02 \mathrm{E} 1$ & $3.07 \mathrm{E} 1$ & 41.8 \\
\hline (89) & $D$ & 10.6 & 22.9 & 39.4 & 24.5 & $\left(10^{3}\right)$ \\
\hline $332 \mathrm{~A}-40-2$ & $\rho_{p}$ & $1.46 \mathrm{E} 1$ & $9.80 \mathrm{E} 0$ & $8.10 \mathrm{E} 0$ & $8.8 \mathrm{E} 0$ & 9.3 \\
\hline (96) & $D$ & 1.8 & 8.8 & 37.2 & 27 & $\left(10^{2}\right)$ \\
\hline $332 \mathrm{~B}-6-1$ & $\rho_{p}$ & $6.41 \mathrm{E}_{1}$ & $6.10 \mathrm{E} 1$ & $5.89 \mathrm{E} 1$ & $5.49 \mathrm{E} 1$ & 61.1 \\
\hline$(100)$ & $D$ & 16.5 & 32.9 & 63.1 & 43.9 & $\left(10^{2}\right)$ \\
\hline $332 \mathrm{~B}-31-1$ & $\rho_{p}$ & $2.50 \mathrm{E} 1$ & $2.31 \mathrm{E} 1$ & $2.17 \mathrm{E} 1_{1}$ & $2.01 \mathrm{E} 1$ & 22.5 \\
\hline (109) & $D$ & 9.3 & 22.4 & 33.5 & 24.6 & $\left(10^{3}\right)$ \\
\hline $334-22-2$ & $\rho_{p}$ & $1.06 \mathrm{E} 2$ & $9.19 \mathrm{E} 1_{1}$ & $8.16 \mathrm{E} 1$ & $7.25 \mathrm{E} 1$ & 94.7 \\
\hline (44) & $D$ & 8 & 11.2 & 17.1 & 23.9 & $\left(10^{2}\right)$ \\
\hline $334-24-4$ & $\rho_{p}$ & $7.46 \mathrm{E} 2$ & $6.51 \mathrm{E} 1$ & $5.83 \mathrm{E} 1$ & $5.37 \mathrm{E} 1$ & 55 \\
\hline$(87)$ & D & 7.8 & 12.6 & 24.2 & 26.1 & $\left(10^{3}\right)$ \\
\hline $335-6-1$ & $\rho_{p}$ & $5.79 \mathrm{E} 2$ & $5.44 \mathrm{E} 1$ & $5.37 \mathrm{E} 1$ & $5.06 \mathrm{E} 1$ & 53.9 \\
\hline (6) & $D$ & 11.6 & 46.6 & 298 & 43.6 & $\left(10^{3}\right)$ \\
\hline
\end{tabular}


TABLE 4

Parallel Resistivity $\left(\rho_{p}\right)$ or Resistivity and Dissipation Factor $(D)$ for Grab Samples from Hudson Deep Drill '74 Site

\begin{tabular}{ccccccc}
\hline \multicolumn{7}{c}{ Frequency } \\
Sample & Parameter & $10^{1}$ & $10^{2}$ & $10^{3}$ & $10^{4} \mathrm{~Hz}$ & $\begin{array}{c}\rho_{p 1} \\
\text { (Freq.) }\end{array}$ \\
\hline $2-1, \mathrm{c}$ & $\rho_{p}$ & $4.49 \mathrm{E} \mathrm{2}$ & $4.39 \mathrm{E} \mathrm{2}$ & $4.24 \mathrm{E} \mathrm{2}$ & $3.96 \mathrm{E} 2$ & 430 \\
& $D$ & 63.2 & 95.7 & 76.3 & 17.8 & $\left(10^{3}\right)$ \\
$6-1, \mathrm{c}$ & $\rho_{p}$ & $1.28 \mathrm{E} \mathrm{2}$ & $1.21 \mathrm{E} \mathrm{2}$ & $1.09 \mathrm{E} \mathrm{2}$ & $9.24 \mathrm{E} 1$ & 74 \\
& $D$ & 31.3 & 20.8 & 14.8 & 13.8 & $\left(10^{4}\right)$ \\
$10-1, \mathrm{~b}$ & $\rho_{p}$ & $1.29 \mathrm{E} 2$ & $1.25 \mathrm{E} \mathrm{2}$ & $1.23 \mathrm{E} \mathrm{2}$ & $1.18 \mathrm{E} \mathrm{2}$ & 120 \\
& $D$ & 51.2 & 142 & 722 & 56.8 & $\left(10^{3}\right)$ \\
$10-2, \mathrm{a}$ & $\rho_{p}$ & $3.62 \mathrm{E} 2$ & $3.53 \mathrm{E} \mathrm{2}$ & $3.41 \mathrm{E} \mathrm{2}$ & $3.19 \mathrm{E} \mathrm{2}$ & 348 \\
& $D$ & 81.5 & 116 & 68.4 & 17.9 & $\left(10^{2}\right)$ \\
$10-3, \mathrm{a}$ & $\rho_{p}$ & $1.53 \mathrm{E} 2$ & $1.49 \mathrm{E} \mathrm{2}$ & $1.48 \mathrm{E} \mathrm{2}$ & $1.39 \mathrm{E} \mathrm{2}$ & 147 \\
& $D$ & 70.6 & 142 & 325 & 30.4 & $\left(10^{3}\right)$ \\
$10-4, \mathrm{~b}$ & $\rho_{p}$ & $5.54 \mathrm{E} 2$ & $5.41 \mathrm{E} \mathrm{2}$ & $5.29 \mathrm{E} \mathrm{2}$ & $4.95 \mathrm{E} \mathrm{2}$ & 539 \\
& $D$ & 71.4 & 116 & 70.7 & 18.8 & $\left(10^{2}\right)$ \\
\hline
\end{tabular}

\section{REFERENCES}

Cole, K.S. and Cole, R.H., 1941. Dispersion and absorption in dielectrics. I Alternating current characteristics. J. Chem. Phys., v. 9, p. 341-351.

Gauvreau, C. and Katsube, T.J., 1975. Automation in electrical rock property measurements: Geol. Surv. Canada, Paper 75-1, part A, p. 83-86.

, 1975b. Electrical parameter conversion table: Geol. Surv. Canada, Paper 75-1, part A, p. 99-100.

Katsube, T.J., 1975a. The critical frequency and its effect on EM propagation: Geol. Surv. Canada, paper 75-1, Part A, p. 101-105. 1975c. The electrical polarization mechanism model for moist rocks: Geol. Surv. Canada, paper 75-1C. , 1975d. Frequency range for mineral differentiation by IP methods: Geol. Surv. Canada, paper 75-1, part A, p. $95-98$.

Katsube, T.J. and Collett, L.S., 1973. Electrical characteristics of rocks and their application to planetary and terrestrial EM-sounding: Fourth Lunar Sci. Conf. Proc, Supplement 4, Geochim. Cosmochim. Acta, Pergamon Press, v. 3, p. 3111-3131.

1974. Electromagnetic propagation characteristics of rocks: Presented at the NATO Advanced Study Institute of Petrophysics, Newcastle-upon-Tyne, England. 